\title{
MAGNETIC SOLID PHASE EXTRACTION APPLICATIONS COMBINED WITH ANALYTICAL METHODS FOR DETERMINATION OF DRUGS IN DIFFERENT MATRICES REVIEW
}

\author{
ŞERIFE EVRIM KEPEKCI TEKKELI $I^{*} A N D$ ZEHRA DURMUS ${ }^{2 *}$ \\ ${ }^{1 *}$ Department of Analytical Chemistry, Faculty of Pharmacy, Bezmialem Vakif University, Fatih, Istanbul, Turkey, \\ $2^{2 *}$ Baglar mah. Gunesli Konutlar No:38, 34212 Bagcilar, Istanbul-Turkey
}

\begin{abstract}
Sample preparation procedures are essential for drug analysis in biological fluids, tissues, pharmaceutical preparations, food and environmental matrices. For this purpose different techniques have been used like protein precipitation, liquid liquid extraction (LLE) and solid phase extraction (SPE). Magnetic solid phase extraction (MSPE) has become a highly preferred method due to its advantages as a sample preparation-pretreatment technique when compared to classical methods as a novel type of SPE. Basically, this type of extraction is based on the separation of different analytes from complex matrices based on the use of magnetic nanoparticles (MNPs) as adsorbents. Magnetic solid phase extraction minimizes the use of additional steps which reduces the manipulation of conventional extractions. The main advantages depend on its simplicity, environmentally friendly process, disposable cost, reduced solvent consumption, and short duration. In this review, special attention is paid on drug analysis by using MSPE prior to various analytical methods from biological, environmental and food matrices. MSPE applications, with various types of magnetic adsorbents, and different analytical method combinations were revealed for drug analysis.

Abbreviations: LLE, liquid liquid extraction; SPE, solid phase extraction; MSPE, magnetic solid phase extraction; DLLME, dispersive liquid-liquid microextraction; SBSE, stir bar sorptive extraction; SPME, solid phase microextraction; SFE, supercritical fluid extraction; PFE, pressurized fluid extraction; MAE, microwave-assisted extraction; MSPD, matrix solid-phase dispersion; MNP, magnetic nanoparticle; SPION, superparamagnetic iron oxide nanoparticles; MRI, magnetic resonance imaging; CE, capillary electrophoresis; UV-Vis, ultraviolet-visible; MS, mass spectrometric; PEI, polyethyleneimine; PVA, polyvinylalcohol; PEG, polyethyleneglycol; PVP, polyvinylpyrrolidone; LC, liquid chromatography; GC, gas chromatography; HPLC, high performance liquid chromatography; FLD, fluorimetric detection; CZE, capillary zone electrophoresis; poly(MAA-co-EDMA), poly methacrylic acid co-ethyleneglycol dimethacrylate LOD, limits of detection; LOQ, limit of quantification; SDS, sodium dodecylsulfate; MPTS, 3-methacryloxypropyl trimethoxysilane; CTAB, cetyltrimethylammonium bromide; MWCNTs, multiwalled carbon nanotubes; DBMNPs, diatomite bonding Fe3O4 magnetic nanoparticles; EGDMA, ethylene glycol dimethacrylate; DCBI, desorption corona beam ionization; MNGO, magnetic nano graphene oxide; NSAIDs, nonsteroidal anti-inflammatory drugs; UAMDSPME, ultrasound-assisted magnetic dispersive solid-phase microextraction; MRLs, maximum residue limits; SA, sulfonamide; PCL, polycaprolactone; MM-PCL-SPE, microspheres solid-phase extraction; MISPE, molecularly imprinted solid-phase extraction; DMIP, dual-template molecularly imprinted polymer; MOF, metal-organic framework; ZIF-8, zeolite imidazolate framework-8; MSPDE, magnetic solid phase dispersion extraction; MIMM, molecularly imprinted magnetic microsphere.
\end{abstract}

Keywords: Magnetic solid phase extraction, biological fluids, drug, high performance liquid chromatography, review.

\section{INTRODUCTION}

Determination of drugs in biological fluids is vital in therapeutic efficacy, bioavailability, bioequivalance studies and forensic toxicological analysis. Biological fluids like urine, plasma, breast milk, cerebrospinal fluid etc and tissues are complex matrices which cause low selectivity and sensitivity. Selective and efficient sample preparation procedures are necessary for quantitation of low dosages of active drug substances. The separation process prior to instrumental analyses should be effective enough to monitorize drug levels to assess toxicity, adverse effects, inter-actions, therapeutic efficiency, pharmacokinetic calculations and quality control of pharmaceutical formulations.

\section{Sample Preparation Techniques}

Drug residues in environmental matrices such as water, food and beverage samples are also very important in order to protect the health and safety of the community.In order to achieve sensitive determinations, like the analytical process, sample preparation (pre treatment process) is also very important. In the anaytical process of biological fluids precipitation is also very important because the appropriateness of extraction methods directly affects many critical consequences due to the analysis such as urine, blood, serum, bile, stomach contents, liver secretion etc. Sample preparation involves steps that include the stages of dilution, precipitation, filtration and centrifugation in environmental, biomedical and pharmaceutical analyzes, and covers a large part of the total analysis time. This process can not be ignored because the accuracy of the extraction steps before the successful application of chromatographic methods directly affects the accuracy of the result of the analysis to be performed. Extraction is typically required to separate and enrich the analytes from the matrix components. The main purpose in preparing the sample is to concentrate, stabilize and eventually bring the target analytes in the sample to the optimal conditions for the desired chromatographic or other analysis. Furthermore, choosing the appropriate sample preparation method is vitally important in qualitative and quantitative determination of the target compounds.
Various methods have been developed in extraction of new techniques for sample pre-treatment. Liquid-liquid extraction (LLE), dispersive liquid-liquid microextraction (DLLME), stir bar sorptive extraction (SBSE), solid phase microextraction (SPME), supercritical fluid extraction (SFE), pressurized fluid extraction (PFE), microwave-assisted extraction (MAE), matrix solid-phase dispersion (MSPD), accelerated solvent extraction and the subject of this review solid phase extraction (SPE) can be counted as the most important methods. SPE plays a crucial role in sample pretreatment, replacing the classical LLE, in biological, food and environmental analyses. SPE is recognized as a beneficial alternative to LLE because it overcomes many drawbacks of the later technique $(1,2)$. It provides low solvent consumption, low intrinsic costs and reduction of processing time. Moreover, it is possible to automate the entire process. Furthermore, SPE does not require separation of phases as mandatory for LLE, which causes errors associated with variable/inaccurately measured extract volumes. In addition, other methods may also cause undesirable conditions such as formation of an emulsion phase during extraction, obtaining extracts without the requisite purity, insufficient removal of the solvents and inability to obtain sensitive quantitative results. Another advantageous feature of the SPE that distinguishes it from LLE is the ability to extract a large number of organic analytes from a wide range of samples.

\section{The application of magnetic nanoparticles (MNPs) to SPE}

The application of magnetic nanoparticles (MNPs) to SPE has received great interest due to their many unique features. The application of MNPs to the extractions process can reduce the overall extraction time in a serious manner, as mentioned above, by ensuring that the equilibrium analyte and the solid phase is achieved with a small amount of sorbent in a short duration. Currently, MSPE, as a sub group of SPE, is preferred by researchers because of its simplicity, environmentally friendly process, low cost, reduced solvent consumption, and short duration. The MSPE implementing steps are nearly the same in all the cited studies in this article, only the magnetic nanoparticle (MNP) type, amount, particle size, MNP and drug interaction period, elution periods, desorption solvent and amount type vary. 
The first analytical application (and the first use of the term MSPE) was developed in 1999 by Safarikova and Safarik for the separation of a copper phthalocyanine dye using silanized magnetite (3). Compared to the SPE used, sample preparation has been greatly simplified with the use of MSPE because the analyte does not need to be trapped in a column and cartridge. The extraction is carried out only by applying a strong external magnetic field. A solution or suspension containing target analytes in MSPE provides selective adsorption on the solid surface by direct contact of analytes with magnetic solid phase nanoparticles incorporated therein.In the last years, several papers have described relevant information on the applications of drug analysis with MSPE Aas can be seen in Figure 1a, This figure also indicates the increase in the number of studies in 1990-2016. Figure 1b also shows the distribution of these studies according to subject area (with solid phase extraction keyword) from SCOPUS.
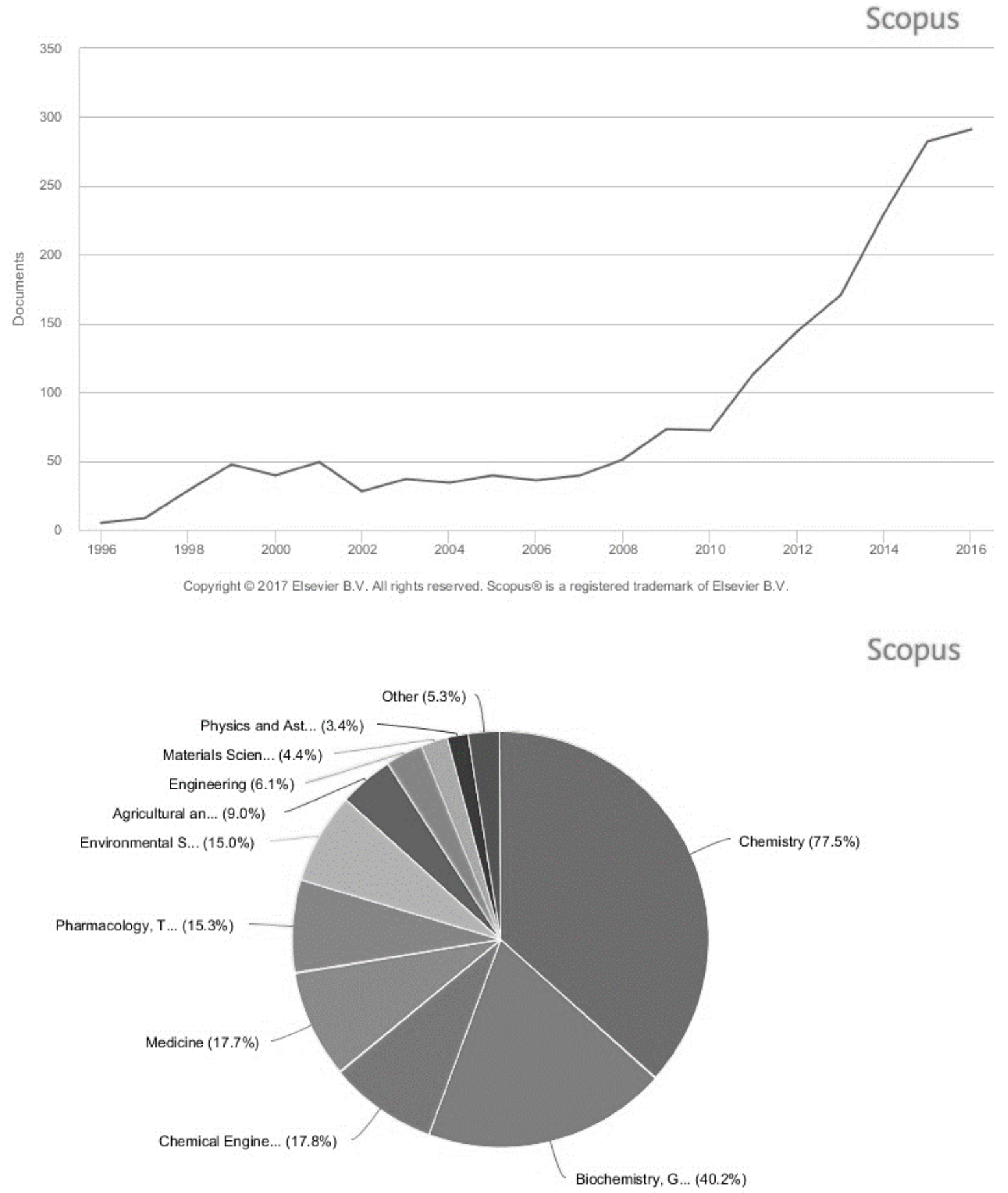

Copyright @ 2017 Elsevier B.V. All rights reserved. Scopus@ is a registered trademark of Elsevier B.V.

Figure 1. Yearly number of publications of MSPE methods used in drug analysis from 1990 to 2016 (above) Subject area of the publications about drug analysis using MSPE from 1990 to 2016 (below). 


\section{Properties of magnetic nanoparticles in MSPE}

MNPs exhibit enhanced magnetic and electrical properties such as high coercivity, low Curie temperature, high magnetic susceptibility and especially superparamagnetism. All these unique features provide the advantages of MNPs for various application areas. Superparamagnetism is a phenomenon that emerged in the form of a single magnetic domain when the particle size is reduced to a diameter range. Opposite to paramagnetic counterparts, superparamagnetic materials do not show remnant magnetization when the external magnetic field is removed. Among superparamagnetic iron oxide nanoparticles (SPIONs), maghemite- $\mathrm{Fe}_{2} \mathrm{O}_{3}$ and magnetite- $-\mathrm{Fe}_{3} \mathrm{O}_{4}$, are the most intensively studied due to their properties making them useful for a variety of applications including magnetic, catalytic, and biomedical areas. In the clinical area, these particles are used as delivery systems for drugs or genes (4), in medical diagnosis (5), hyperthermia (6), cell separation (7) and magnetic resonance imaging (MRI) contrast enhancement $(, 8)$ and therapy (9).

Most of these applications require chemically stable, well-dispersable particules with a size smaller than $100 \mathrm{~nm}$ and uniform physical and chemical properties. The size and morphology of magnetite NPs could be controlled by varying synthesis methods, shown in Figure 2, such as co-precipitation (10), thermal decomposition (11), solvothermal (polyol) (12), hydrothermal (13), green synthesis (14), microemulsion (15), flow injection (16), Oswald ripening (17), sonochemical (18), electrodeposition (19), microwave (20) and biological (21).

One of the effective approaches for preventing particle agglomeration is to functionalize the surface of the MNPs with polymers or other targeting agents, taking into account their biocompatibility, biodegradability and low toxicity. Surface functionalized SPIONs are a group of novel functional materials, which have been widely used in biotechnology and bioscience.

The surface of the MNPs can be modified by inorganic materials such as amorphous or mesoporous silica (22), metals like Ag, Au, Pd and P26), mannose (27), carrageenan (28) and polymers such as polyethyleneimine (PEI) (29), polyvinylalcohol (PVA) (30), polyethyleneglycol (PEG) (31), and polyvinylpyrrolidone (PVP) (32) to avoid the formation of aggregates and to facilitate the adsorption of various biological ligands.

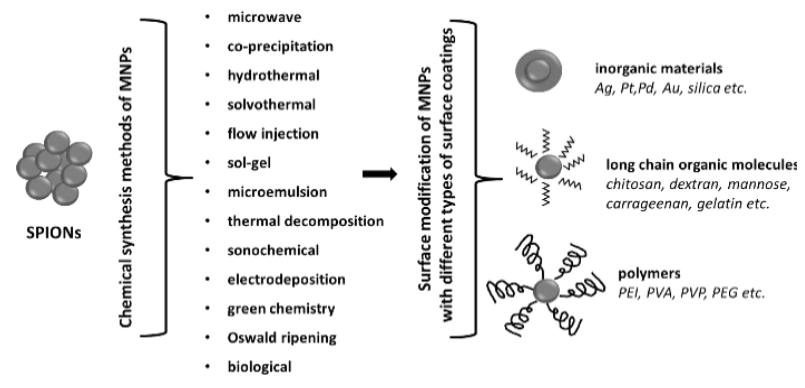

Figure 2: Chemical synthesis methods and surface modification routes of MNPs used in biomedical applications.

\section{Analytical Determination}

Generally, at first MNPs were added into the sample and mixed for a few minutes in order to provide the adsorption of the analyte or analytes onto the MNPs' surface. Then by an external magnetic field (by using a magnet) the MNPs accumulated on one side of the test tube and the supernatant were drained easily. Subsequently, MNPs were washed with suitable desorption solvent and the anayte/s were eluted with the solvent. The eluate (extract) can be directly injected to the chromatographic or capillary electrophoretic (CE) system or sometimes direct ultraviolet-visible (UV-Vis) spectophotometric and fluorimetric and mass spectrometric (MS) procedures can be carried out. The MSPE process was schematized in Figure 3. The $\mathrm{pH}$ of the sample medium, the mixing time (MNP and drug interaction period) and the amount, the type of MNPs, the volume of desorption solution and the washing period are the parameters that are optimized for every MSPE study.

In this review article, the MSPE applications for drug analyses are investigated according to their matrix type and divided into subsections as biological, environmental and food matrices. Mostly liquid chromatography (LC) methods were combined with MSPE, also there is gas chromatography (GC), direct UV-Vis spectrophotometry and fluorimetry, MS methods were also presented and two combination with capillary electrophoresis (CE) methods are reported in the literature.
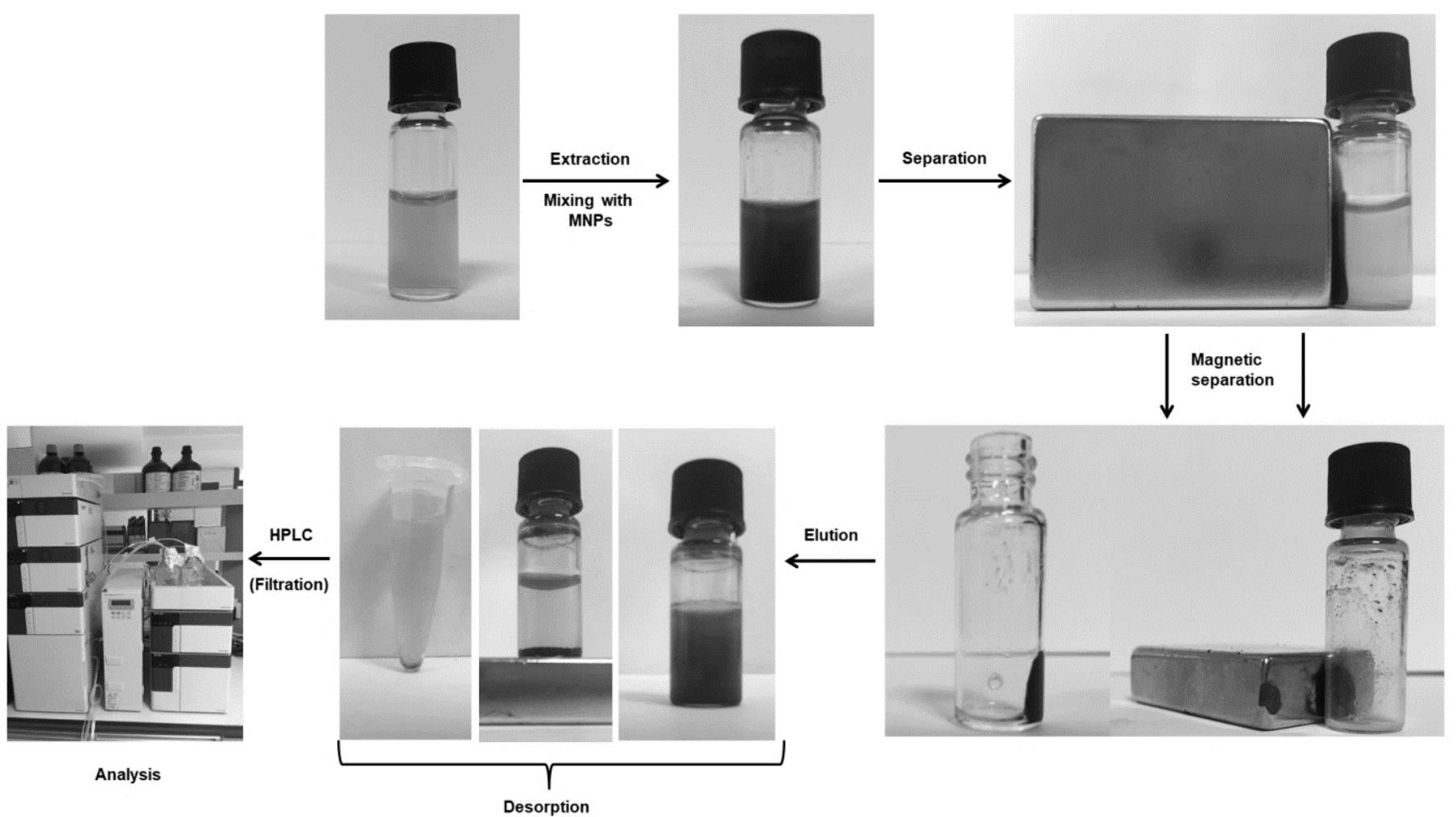

Analysis

Desorption

Figure 3: General procedure for MSPE. 


\section{Determinations in Biological Matrices}

Because the drug concentration is low and the biological fluids are matrixstructured, sample clearance and preconcentration must be performed prior to drug identification. MSPE is a solvent-free, simple, rapid and attractive common sample preparation technique for chromatographic pre-treatment of complex sample matrices for clinical and pharmaceutical analysis due to its advantages For this purpose, the most widely used types of nanoparticles in SPE are silica, alumina and silica-based sorbents, polymer sorbents, carbon nanoparticles such as graphite, porous carbon or carbon nanotubes (CNTs), molecular imprint polymers, functionalized resins, etc.

Due to its physico-chemical properties, silica is the most advantageous material for coating in bioanalytical use of magnetic cores. However, it is difficult to obtain a completely nanoporous silica coating and thus maintain its stability. Therefore, these structures may be shell-core or mesoporous. However, the solution of the above mentioned stability difficulties seem to be polymer coatings. The use of polymers ensures that the desired colloidal distribution results in a large surface area and stability and biocompatibility (33). In Table 1, the methods are listed with MSPE type, synthesis way and characterization procedures, the combined anaytical method and other detailed information.

For the determination of two important anthraquinones, which have several medicinal effects, rhein and emodin were determined in human urine and serum by high performance liquid chromatography (HPLC) with fluorimetric detection (FLD). The $\mathrm{Fe}_{3} \mathrm{O}_{4}$ and $\mathrm{SiO}_{2}$ core nanoparticles (NPs), as a mixed hemimicelles based nanosized SPE sorbent were modified by coating with cationic surfactants to prepare the MSPE sorbents. A short shaking time was enough for the required efficiency. By this the MSPE application, the recoveries of both analytes in both matrices (urine and plasma) were around $95 \%$ withC 18 column.It is mentioned in this study that good linearities and recoveries with serum and urine samples for both analytes indicate that this proposed method is feasible (34).

Eight illegal drugs (acetyl codeine, amphetamine, codeine, ethylene dimethacrylate, heroine, ketamine, methamphetamine, 3,4methylenedioxyamphetamine) were determined in urine by MSPE coupled to capillary zone electrophoresis (CZE) technique with UV-Vis detection. As the extraction sorbent $\mathrm{Fe}_{3} \mathrm{O}_{4} / \mathrm{SiO}_{2} /$ poly(MAA-co-EDMA) magnetic microspheres were used. After adding MNPs, these eight drugs were isolated from the urine matrix by an external magnetic field. After removing the supernatant solution, the magnetic microspheres were washed with ultrapure water twice. Then, analytes were eluted from the sorbent particles with acetone containing $0.5 \%$ formic acid. The eluent was evaporated to dryness then dissolved in ultrapure water before applying to the CE system. The limits of detection (LOD) for the eight analytes varied from 0.015 to $0.105 \mu \mathrm{g} / \mathrm{mL}$.(35).

A CE method with FL detection was developed for the determination of alendronate which is a widely used drug substance for osteoporosis and other bone diseases. Prior to $\mathrm{CE}$, as the sample pretreatment procedure, MSPE was used with $\mathrm{Al}_{2} \mathrm{O}_{3}$ coated $\mathrm{Fe}_{3} \mathrm{O}_{4}$ nanoparticles. NPs were ultrasonically washed twice with $0.5 \mathrm{~mL}$ of $150 \mathrm{mM}$ phosphate buffer solution ( $\mathrm{pH}$ 9.0) for $5 \mathrm{~min}$, and the supernatant liquid was discarded. A $55 \mathrm{~cm}$ length capillary was used with a separation voltage of $24 \mathrm{kV}$ in 5 min until completion the electropherogram. An interesting point in this study is that for the plasma assay prior to SPE a deproteinization procedure using acetonitrile in $1: 1 \mathrm{v} / \mathrm{v}$ ratio to plasma was utilized. Because of the compexity of plasma and the difficulty to isolate alendronate from plasma proteins, an additional step was conducted before MSPE. Besides, in order to gain high fluorescence after MSPE and before CE injection the analyte was a precolumn derivatized with 2,3-naphthalene dicarboxyaldehyde (36).

$\mathrm{Fe}_{3} \mathrm{O}_{4}$ nanoparticles were modified with $\mathrm{Ag}$ in order to assess an efficient extraction for a cephalosporin antibiotic, ceftriaxone. Following the extraction, the extract was injected to an HPLC system with UV detection by an isocratic elution using a C 18 column. LOD and the limit of quantification (LOQ) were 20 and $60 \mathrm{ng} / \mathrm{mL}$, respectively. The recovery of MSPE was $89 \%$ and no other purification was required (37).

To quantify oxymetholone which is an important synthetic anabolic steroid MSPE was used as pre treatment procedure and immediately after spectrophotometric assay was conducted. The amount of oxymetholone and its major metabolite mestanolone are the markers of drug abuse. It is reported as a prohibited substance by World Anti-Doping Agency. In this study $\mathrm{Fe}_{3} \mathrm{O}_{4}$ was coated with sodium dodecylsulfate (SDS).
MNPs were prepared according to a previously reported procedure (38). After that, $\mathrm{Fe}_{3} \mathrm{O}_{4}$ treated with SDS solution and the residue of the surfactant was washed with double distilled water. Desorption of the drug was performed with acetonitrile. The method provides a wide range for quantitation with the linearity $15-3300 \mathrm{ng} / \mathrm{mL}$ at $530 \mathrm{~nm}(39)$.

Letrozole is a third-generation aromatase inhibitor, and it is widely used for malignant breast cancer theraphy. In this research, $\mathrm{Fe}_{3} \mathrm{O}_{4}$ was synthesized by the co-precipitation method (40), and the free-radical graft co-polymerization of 1 (N,N-bis-carboxymethyl carboxymethyl) amino-3-allylglycerol, a functional monomer, and $\mathrm{N}, \mathrm{N}$-dimethylacrylamide onto magnetic nano-particle surface modified with (3-mercaptopropyl) trimethoxy silane. The polymer-grafted magnetic nano-sorbent provided efficient extraction for letrozole and after MSPE the extract was directly injected to the HPLC system. C 18 column and the mobile phase of acetonitrile and a phosphate buffer $(\mathrm{pH} 6.8)(56: 44 \mathrm{v} / \mathrm{v})$ at a flow rate of $1 \mathrm{~mL} / \mathrm{min}$ in isocratic elution mode was completed (41)

By using MNPs modified by tetraethyl orthosilicate and 3 methacryloxypropyl trimethoxysilane (MPTS), the antiepileptic drug substance lamotrigine was isolated from human urine and plasma and determined by HPLC with UV detection. The magnetic molecularly imprinted polymers were prepared by a surface molecular imprinting technique. As a desorption solution, methanol/TFA/acetic acid (96:2:2, v/v/v) was used, the eluate was evaporated and the residue was dissolved in the mobile phase and directly injected into the HPLC system. The sensitivity of the method is $0.7 \mu \mathrm{g} / \mathrm{mL}$ for urine and 0.5 $\mu \mathrm{g} / \mathrm{mL}$ for plasma (42).

The MSPE method was developed with magnetic mixed hemimicelles. The MNPs $\left(\mathrm{Fe}_{3} \mathrm{O}_{4}\right)$ were synthesized via a simple chemical coprecipitation method (43) and positively charged cetyltrimethylammonium bromide (CTAB) ions were coated to the surface of negatively charged $\mathrm{Fe}_{3} \mathrm{O}_{4} \mathrm{NPs}$ in a basic medium. Then, naproxen was extracted from the matrix by adsorption onto the MNPs. Desorption solvent was chosen as methanol according to the optimization studies. Recoveries were approximately 98.6 for urine and 98.4 for plasma. The extraction processes were completed in eight minutes. The extract was directly injected to HPLC-UV system. C 18 column were used the mobile phase was a mixture of acetonitrile-acetic acid with isocratic elution. Naproxen was detected at $230 \mathrm{~nm}(44)$.

Fluoxetine, is a selective serotonin reuptake inhibitor, it is widely used for depression therapy. In order to determine the amount of fluoxetine in human urine magnetic multiwalled carbon nanotubes (MWCNTs) were used as the absorbent. MWCNTs $/ \mathrm{Fe}_{3} \mathrm{O}_{4}$ were synthesized according to previously published methods $(45,46)$. The total extraction time was $25 \mathrm{~min}$. Subsequently, a reaction with a p-acceptor reagent, 2,3-dichloro-5,6-dicyanobenzoquinone was conducted to form a charge transfer complex. Depending on the high molar absorptivity, fluoxetine was determined by spectrophotometry at $470 \mathrm{~nm}$. LOD and LOQ of the developed method were 0.06 and $0.19 \mathrm{mg} / \mathrm{mL}$, respectively (47).

Another MWCNTs study was published for two illegal basic drugs, methamphetamine and ketamine in human urine and whole-blood samples. In this study MWNTs were combined with GC-MS where the ionization source of MS was electron impact. $\mathrm{Fe}_{3} \mathrm{O}_{4}$ nanoparticles were attached to the MWCNTs surface by a chemical co-precipitation method (48) with minor adjustments. The extraction time was 10 minutes with high recoveries (49).

In another study a polymer coating application is used for serotoninnorepinephrine reuptake inhibitor class antidepressant drug substance venlafaxine. This time MSPE was combined with spectrofluorimetry in human urine and plasma assays. Desorption solvent was methanol and $\mathrm{HCl}$ mixture. The LOQ was nearly $2 \mathrm{ng} / \mathrm{mL}$ for both matrices (50).

The second venlafaxine assay by using MSPE in the litareture depends on the organic functionalization of $\mathrm{Fe}_{3} \mathrm{O}_{4}$ with silane-coupling agent 3methacryloxypropyltrimethoxysilane (KH-570). This agent improves the efficiency of the extraction process by providing cross links. GC-FID was used as the analytical method in hair samples and environmental aqueous samples. The extract was desorbed by methanol and subsequently injected into the GCFID system for analysis (51). 
For the fluorimetric determination of doxazosin and alfuzosin, a mixed micelle surfactant sodium dodecyl sulfate and non-ionic polyoxyethylene (7.5) nonylphenylether were used as the extractant, and diatomite bonding $\mathrm{Fe}_{3} \mathrm{O}_{4}$ magnetic nanoparticles (DBMNPs) were used as the adsorbent. A two-step extraction technique was used to isolate the drugs from pharmaceutical preparations, urine samples, and plasma samples. In the extraction process micelle solution was mixed with the sample and $\mathrm{NaCl}$ solution, then DBMNPs were added and sonicated for $2 \mathrm{~min}$. The DBMNPs were rapidly collected from the tube wall using a strong magnet, and the supernatant was decanted. Ethanol was used to desorp the drugs from the MNPs surface. The extract's fluorescence intensity was measured at 330 with $381 \mathrm{~nm}$ emission for doxasozin and 332 with $383 \mathrm{~nm}$ emission for alfuzosin. This method provides simple and fast analysis for these two drugs which are effective in hypertension treatment (52).

For the determination of p-nitroaniline treated amoxicillin in human urine samples,dibenzo-18-crown-6 modified magnetic-multiwalled carbon nano tubes, which are synthesized and characterized, were used prior to its spectrophotometric determination; on the other hand the conditions (such as $\mathrm{pH}$, amount of the adsorbent) etc. of extraction process were optimized. Recovery was $99.9 \%(53)$.

A study describes a method for the determination of codeine in human urine by spectrofluorimetry. $\mathrm{Fe}_{3} \mathrm{O}_{4}$ was used as a core and polymeric adsorbent was synthesized with aminoimide monomer as the functional monomer and ethylene glycol dimethacrylate (EGDMA) as the cross-linker, and ammonium persulfate as the initiator. $97.7 \%$ recovery was achieved. After the extraction process at $214 \mathrm{~nm}$ emisson and $348 \mathrm{~nm}$ excitation $\mathrm{ng} / \mathrm{mL}$ level codeine was determined in urine (54)

Pyrrole-coated $\mathrm{Fe}_{3} \mathrm{O}_{4}$ magnetic nanoparticles were prepared and used for the extraction of antidepressant drug substances citalopram, sertralin and fluoxetine. After isolation of these drugs, the determination was assesed by MS, the ionization source was desorption corona beam ionization (DCBI). DCBI-MS analysis was very short with $3 \mathrm{~min}$ of duration. The most interesting point in this study is the absence of desorption step for MSPE. Besides as direct detection was possible with DCBI-MS, no separation process like chromatography was required (55).

A new method was described for the determination of methamphetamine from urine samples using MSPE combined with HPLC-UV. The sorbent was a magnetic nano graphene oxide (MNGO) and it was synthesized by Hummer's method (56). The mobile phase of acetonitrile/phosphate buffer solution was used in isocratic mode with C 18 column. Drug free samples from the volunteers and drug positive samples from related drug abuse centers were both centrifuged to provide the sedimentation of lipidic solid components. The supernatant was subjected to MSPE and the MSPE conditions were optimized. Acetone was preferred as the desorption solvent. MNGO was more efficient in comparison with pure $\mathrm{Fe}_{3} \mathrm{O}_{4}$. The reason is the higher surface area and the presence of polar groups on the surface. This method is feasible for forensic analysis with the LOQ of $100 \mathrm{ng} / \mathrm{mL}(57)$.
In another method, amphetamine and methadone were determined simultaneously in human urine. The LOQ was $100 \mathrm{ng} / \mathrm{mL}$ for both analytes. This method is also useful to evaluate drug abuse. Magnetic graphene oxide was used as the sorbent. Its way of synthesizing and characterization were explained in previous works (58-60). A centrifugation step was applied before MSPE in order to provide the precipitation of lipidic constituents of urine. The recovery values were $94 \%$ for amphetamine and $96 \%$ for methadone after this efficient extraction reverse phase HPLC with UV detection (61).

Magnetic ethylendiamine-functionalized graphene oxide nanocomposite was used as the extraction sorbent for the extraction of cow milk, human urine, river, and water samples for the determination of two of the NSAIDs, naproxen and ibuprofen. This study is related to all the subsections of this review article with different matrices applyingultrasound-assisted magnetic dispersive solidphase microextraction (UAMDSPME) technique $(62,63)$. In this technique the MNPs were dispersed in water by a compact hand-held ultrasonic and urgently injected into the sample solution for extraction. For urine samples the recovery was $86.4 \%$ for naproxen and $88.6 \%$ for ibuprofen. C18 analytical column $(6.4$ $\mathrm{mm} \times 250 \mathrm{~mm}, 5.1 \mu \mathrm{m})$ and the mobile phase of acetonitrile/ formic acid-sodium formate buffer $(\mathrm{pH} 4) /$ methanol $(20: 40: 40, \mathrm{v} / \mathrm{v} / \mathrm{v})$ was delivered at a flow rate of $1.0 \mathrm{~mL} / \mathrm{min}$. The photodiode-array detector was set at the wavelength of $225 \mathrm{~nm}$ (64).

Amlodipine and carvedilol are generally used as a combination in pharmaceutical formulations for hypertensive theraphy. $\mathrm{Fe}_{3} \mathrm{O}_{4} \mathrm{NPs}$ were synthesized and coated with sodium dodecyl sulfate (SDS) and used as an extraction sorbent. Desorption solvent was acetonitrile and $20 \mu \mathrm{L}$ of the eluate was injected to the HPLC-UV system. The recovery was calculated by the following equation: Recovery $\left.\%=\left[\left(\mathrm{C}_{\text {found }}-\mathrm{C}_{\text {real }}\right)\right] / \mathrm{C}_{\text {added }}\right] \times 100$ where $\mathrm{c}$ found, $\mathrm{c}$ real and $\mathrm{c}$ added are the concentrations of analytes measured in spiked samples after MSPE, analytes in real samples after MSPE and the known amount of standards added to the real sample, respectively. The recovery was about $90 \%$ (65).

MNPs with phenyl functionalized core and a hydrophilic methylcellulose coating were synthesized by the solvothermal method and used for the sample preparation of sildenafil and its metabolite desmethylsildenafil prior to liquid chromatographic determination in plasma and urine. . No other pretreatment procedure was required and sensitive analysiswere provided for this widely used drug and its major metabolite in $\mathrm{ng} / \mathrm{mL}$ level (66).

In the bioassay, MNPs are used to isolate inorganic and organic compounds from biological samples, as shown in the studies detailed above. Table 1 summarizes information on the application of MNPs for the isolation and enrichment of analytes from biological samples. Analytical examination of biological specimens containing complex matrices that preclude direct analysis of blood, urine, saliva, bile, sperm etc. is a major challenge for analysts. Biological samples were usually detected by treating with the surface functionalized MNPs to target analytes. 
Table 1: The main parameters of MSPE and analytical process combination of drug determinations in biological samples.

\begin{tabular}{|c|c|c|c|c|c|c|c|c|c|}
\hline Analyte & Matrix & MNP type & MNP synthesis method & MNP characterization & $\begin{array}{c}\text { MSPE } \\
\text { recovery } \%\end{array}$ & $\begin{array}{c}\text { Desorption } \\
\text { solvent/elution } \\
\text { process }\end{array}$ & $\begin{array}{c}\text { Additional } \\
\text { step before or after } \\
\text { MSPE }\end{array}$ & $\begin{array}{c}\text { Combined } \\
\text { analytical } \\
\text { method }\end{array}$ & Ref \\
\hline $\begin{array}{l}\text { rhein } \\
\text { emodin }\end{array}$ & $\begin{array}{l}\text { urine } \\
\text { plasma }\end{array}$ & $\begin{array}{c}\text { CTAB coated } \\
\mathrm{Fe}_{3} \mathrm{O}_{4} / \mathrm{SiO}_{2}\end{array}$ & coprecipitation & TEM, IR & 95 & $\begin{array}{c}\text { acetonitrile: } 1 \% \\
\text { acetic acid }\end{array}$ & - & HPLC-FLD & -42 \\
\hline $\begin{array}{l}\text { ketamine } \\
\text { amphetamine } \\
\text { opiates } \\
\text { ( } 8 \text { illegal drugs) }\end{array}$ & urine & $\begin{array}{c}\mathrm{Fe}_{3} \mathrm{O}_{4} / \mathrm{SiO}_{2} / \text { poly } \\
\text { (MAA-co-EDMA) }\end{array}$ & $\begin{array}{c}\text { precipitation, } \\
\text { polymerization (61) }\end{array}$ & XRD, TEM, FTIR & $85.4-110.1$ & $\begin{array}{c}\text { acetone: } 0.5 \% \text { formic } \\
\text { acid }\end{array}$ & - & CZE-UV-Vis & -43 \\
\hline alendronate & $\begin{array}{c}\text { urine } \\
\text { plasma }\end{array}$ & $\mathrm{Al}_{2} \mathrm{O}_{3}$ coated $\mathrm{Fe}_{3} \mathrm{O}_{4}$ & - & - & $\begin{array}{c}104.5 \text { urine } \\
101.5 \text { plasma }\end{array}$ & $\begin{array}{c}\mathrm{Na}_{5} \mathrm{P}_{3} \mathrm{O}_{10} \text { solution } \\
(\mathrm{pH} 9.0) .\end{array}$ & $\begin{array}{c}\text { derivatization for FLD } \\
\text { after MSPE }\end{array}$ & CE-FLD & -44 \\
\hline ceftriaxone & plasma & $\mathrm{Ag}$ coated $\mathrm{Fe}_{3} \mathrm{O}_{4}$ & coprecipitation & XRD, TEM, FTIR, UV-Vis & 89 & $\begin{array}{c}0.05 \mathrm{M} \text { phosphate } \\
\text { buffer }\end{array}$ & - & HPLC-UV & -45 \\
\hline $\begin{array}{l}\text { oxymetholone } \\
\text { mestanolone }\end{array}$ & urine & SDS coated $\mathrm{Fe}_{3} \mathrm{O}_{4}$ & coprecipitation (38) & XRD, TEM, FTIR & 99.7 & acetonitrile & - & UV-Vis & -47 \\
\hline letrozole & $\begin{array}{c}\text { serum } \\
\text { urine }\end{array}$ & polymer-grafted $\mathrm{Fe}_{3} \mathrm{O}_{4}$ & coprecipitation (40) & XRD, TEM, FTIR, SEM, TGA & $\begin{array}{l}95 \text { urine } \\
81.5 \text { serum }\end{array}$ & $\begin{array}{c}\text { acetonitrile:TFA } \\
(94: 1: 5(\mathrm{v} / \mathrm{v})) \\
\end{array}$ & - & HPLC-UV & -49 \\
\hline lamotrigine & $\begin{array}{l}\text { urine } \\
\text { plasma }\end{array}$ & $\mathrm{Fe}_{3} \mathrm{O}_{4} @ \mathrm{SiO}_{2}$ & $\begin{array}{c}\text { surface } \\
\text { molecular imprinting, }\end{array}$ & XRD, SEM, FTIR, TGA & $\begin{array}{l}97.5 \text { urine } \\
96.8 \text { plasma }\end{array}$ & $\begin{array}{c}\text { methanol:TFA: } \\
\text { acetic acid }(96: 2: 2, \\
\mathrm{v} / \mathrm{v} / \mathrm{v})\end{array}$ & - & HPLC-UV & -50 \\
\hline naproxen & $\begin{array}{l}\text { urine } \\
\text { plasma }\end{array}$ & CTAB coated $\mathrm{Fe}_{3} \mathrm{O}_{4}$ & coprecipitation (43) & FTIR, TEM, XRD & $\begin{array}{l}98.9 \text { urine } \\
98.4 \text { plasma }\end{array}$ & $\begin{array}{c}\text { methanol: } \\
\text { acetonitrile (1:5) } \\
\end{array}$ & - & HPLC-UV & -52 \\
\hline fluoxetine & urine & MWCNTs $/ \mathrm{Fe}_{3} \mathrm{O}_{4}$ & $\begin{array}{l}\text { MWCNT oxidation (45) } \\
\text { coprecipitation (46) }\end{array}$ & FTIR, TEM, XRD & 99.4 & acetonitrile & $\begin{array}{l}\text { charge transfer } \\
\text { complexation (after } \\
\text { MSPE) }\end{array}$ & UV-Vis & -55 \\
\hline $\begin{array}{l}\text { methamphetamine } \\
\text { ketamine }\end{array}$ & $\begin{array}{c}\text { urine } \\
\text { whole blood }\end{array}$ & MWCNTs/ $/ \mathrm{Fe}_{3} \mathrm{O}_{4}$ & coprecipitation (48) & TEM, XRD & $\begin{array}{c}86.6 \text { urine } \\
81.4 \text { blood for MA } \\
93.6 \text { urine }\end{array}$ & ethyl acetate & $\begin{array}{l}\text { protein precipitation } \\
\text { (before MSPE) }\end{array}$ & GC-MS & -57 \\
\hline venlafaxine & $\begin{array}{l}\text { urine } \\
\text { serum }\end{array}$ & EGDMA coated $\mathrm{Fe}_{3} \mathrm{O}_{4}$ & $\begin{array}{l}\text { polymerization onto } \\
\text { magnetic core }\end{array}$ & FTIR, VSM, XRD, TEM & - & methanol: $\mathrm{HCl}$ & - & $\begin{array}{l}\text { spectro } \\
\text { fluorimetry }\end{array}$ & -58 \\
\hline venlafaxine & $\begin{array}{c}\text { hair river } \\
\text { water surface } \\
\text { water } \\
\end{array}$ & silanized $\mathrm{Fe}_{3} \mathrm{O}_{4}$ & coprecipitation & FTIR, XRD, TEM & $\begin{array}{c}89.4 \text { hair } \\
93.4 \text { river water } \\
95 \text { surface water } \\
\end{array}$ & methanol & $\begin{array}{c}\text { washing and } \\
\text { incubation (before } \\
\text { MSPE) } \\
\end{array}$ & GC-FID & -59 \\
\hline $\begin{array}{l}\text { doxazosin } \\
\text { alfuzosin }\end{array}$ & $\begin{array}{l}\text { urine } \\
\text { plasma }\end{array}$ & $\begin{array}{c}\text { diatomite bonding } \\
\mathrm{Fe}_{3} \mathrm{O}_{4}\end{array}$ & - & - & 85.2-118.7-both matrices & - & - & MS & -60 \\
\hline amoxicillin & urine & $\begin{array}{c}\text { surface } \\
\text { modified MWCNTs }\end{array}$ & surface modification & FTIR, XRD, TEM & 99.9 & - & $\begin{array}{c}\text { formation of a colored } \\
\text { azo-derivative (after } \\
\text { MSPE) } \\
\end{array}$ & UV-Vis & -61 \\
\hline codeine & urine & EGDMA coated $\mathrm{Fe}_{3} \mathrm{O}_{4}$ & solvothermal reduction & FTIR, XRD, TEM & 98 & methanol & - & $\begin{array}{l}\text { spectro } \\
\text { fluorimetry }\end{array}$ & -62 \\
\hline $\begin{array}{l}\text { citalopram, } \\
\text { sertraline } \\
\text { fluoxetine }\end{array}$ & $\begin{array}{l}\text { urine } \\
\text { plasma }\end{array}$ & pyrrole coated $\mathrm{Fe}_{3} \mathrm{O}_{4}$ & - & FTIR, TEM & - & - & - & DCBI-MS & -63 \\
\hline methamphetamine & urine & $\begin{array}{c}\text { graphene oxide coated } \\
\mathrm{Fe}_{3} \mathrm{O}_{4} \\
\end{array}$ & $\begin{array}{c}\text { graphene oxidation (56), } \\
\text { coprecipitation }\end{array}$ & FTIR, SEM, XRD, VSM & 91.7 & acetone & - & HPLC-UV & -65 \\
\hline $\begin{array}{l}\text { amphetamine } \\
\text { methadone }\end{array}$ & urine & $\begin{array}{c}\text { graphene oxide coated } \\
\qquad \mathrm{Fe}_{3} \mathrm{O}_{4}\end{array}$ & $\begin{array}{c}\text { graphene } \\
\text { oxidation }(58-60) \\
\text { coprecipitation }\end{array}$ & - & $\begin{array}{l}93.87 \text { amphetamine } \\
96.58 \text { methadone }\end{array}$ & acetonitrile & - & HPLC-UV & -69 \\
\hline $\begin{array}{l}\text { naproxen } \\
\text { ibuprofen }\end{array}$ & $\begin{array}{c}\text { cow milk } \\
\text { human urine } \\
\text { river } \\
\text { well water }\end{array}$ & $\begin{array}{c}\text { functionalized } \\
\text { graphene oxide coated } \\
\mathrm{Fe}_{3} \mathrm{O}_{4}\end{array}$ & $\begin{array}{c}\text { graphene } \\
\text { oxidation } \\
\text { precipitation }(62,63)\end{array}$ & FTIR & $\begin{array}{l}\text { 86.4-104.6 naproxen } \\
\text { 88.6-95.8 ibuprofen }\end{array}$ & methanol & $\begin{array}{c}\text { ultrasonication } \\
\text { centrifugation }\end{array}$ & HPLC-DAD & -72 \\
\hline $\begin{array}{l}\text { amlodipine } \\
\text { carvedilol }\end{array}$ & urine & SDS coated $\mathrm{Fe}_{3} \mathrm{O}_{4}$ & coprecipitation & TEM & $\begin{array}{l}85.06 \text { amlodipine } \\
88.6 \text { carvediol }\end{array}$ & acetonitrile & - & HPLC-UV & -73 \\
\hline sildenafil & $\begin{array}{c}\text { urine } \\
\text { plasma }\end{array}$ & $\begin{array}{c}\text { methylcellulose coated } \\
\qquad \mathrm{Fe}_{3} \mathrm{O}_{4}\end{array}$ & solvothermal method & FTIR, TGA & - & $\begin{array}{c}\text { methanol:water: } \\
\mathrm{CH}_{3} \mathrm{COOH}\end{array}$ & - & HPLC-DAD & -74 \\
\hline
\end{tabular}

\section{Determinations in Environmental Matrices}

One of the most important consequences of the developments in microbiology is that it opens the way of making antibiotics through synthesis. Since the discovery of antibiotics, a broader set of natural microbial compounds has been described in several medical, veterinary and agricultural applications with antibacterial, antifungal, antiviral, antitumor or pesticidal activities. This has led to the accumulation of antibiotic residues in the environment, along with the widespread use of antibiotics in various areas. For example, allergic reactions to antibiotics can put the immune system at risk, as antibiotic residues can cause a harmful effect on human and animal health and to smaller extent plants. In many countries monitoring obligations have been established to determine antibiotic levels in food and water. The studies carried out in order to determine drug pollutants in environmental matrices by magnetic solid phase extraction methods are summarized in Table 2 and the details are examined below.

Sulfonamide (SA) antibiotics can easily contaminate environmental water because of their anionic characteristics. To determine the level of exposure, a new HPLC method was developed. Before the chromatographic process, MSPE was applied to waste water samples by using graphene coated $\mathrm{Fe}_{3} \mathrm{O}_{4}$ as the extraction sorbent. By using graphen the surface was widened and high recoveries were provided. The LOD for three SA antibiotics (sulfadiazine, sulfamerazine, sulfamethoxazole) ranged from 0.43 to $0.57 \mathrm{ng} / \mathrm{mL}$. This sensitive analyse did not require any pretreatment procedure other than MSPE (67).

Ten SA antibiotics were determined from commercial milk samples by using MSPE combined with LC-MS-MS. The MNPs were graphene oxide coated $\mathrm{Fe}_{3} \mathrm{O}_{4}$. They were synthesized according to Hummer's method (35) and characterized by FTIR and TEM. This method provides the evaluation of milk quality as a food product (68).

Dopamine has a self-polymerization capacity in the aqueous phase and depending on this property it provides the formation of a surface-adhesive film onto the $\mathrm{Fe}_{3} \mathrm{O}_{4}$ core. By using this combination as a MSPE sorbent, 12 estrogenic compounds were isolated from mineral, tap and wastewater samples and determined by ESI sourced LC-MS. Validation of the entire method was carried out, obtaining good repeatability and reproducibility while LODs and LOQs are in the range of $0.01-0.34 \mathrm{ng} / \mathrm{L}(69)$. 
Seventeen $\beta$-estradiol exist in lake water, river water and effluent, which causes a potential risk for environmental and human health and this were investigated by an HPLC-UV assay. A pretreatment procedure was carried out by using aldehyde groups to the surface of amino-functionalized magnetic nanoparticles that are imprinted with gelatin. UV detection provides sensitive analysis in $\mathrm{ng} / \mathrm{mL}$ levels in this study (70).

In another method raniditine was determined in well and tap water samples and human plasma. MSPE was used for sample pretreatment and also for preconcentration in aquatic samples. $\mathrm{Fe}_{3} \mathrm{O}_{4}$ NPs were modified by SDS as a sorbent. The structure of the sorbent was characterized with SEM. In 5 minutes, the extraction was performed by using methanol as the desorption solvent. Before extraction of the plasma samples, protein precipitation was also performed. The extraction recovery in human plasma and different matrixes of waters were investigated and values of $89.0 \%$ to $103.4 \%$ were obtained. The determinations were carried out spectrophotometrically at $320 \mathrm{~nm}$ in $\mu \mathrm{g} / \mathrm{mL}$ level (71).

For the determination of an important antiviral drug, active substance lamivudine, which is widely prescribed in HIV infections, an HPLC-DAD method was developed by using MMWCNTs prepared by assembling Ni. By this modification the adsorption ability of the sorbent improved and efficient extraction procedures were performed in human urine and environmental water samples (river water). There is an additional novelty in this study depending on the desoption solvent. The extracted lamivudine was desorbed using ionic liquid (IL) which are known as "Green solvents" as substitutes of volatile organic solvents. The ILs are the salts in a liquid state and have attracted great attention due to their unique chemical and physical properties such as nonvolatility that preserves the environment and high adsorption capacity. The recoveries were above $90 \%$. C $18(150 \mathrm{~mm} 4.6 \mathrm{~mm}, 5 \mathrm{~mm})$ column and phosphate buffer $(\mathrm{pH}$ $3.5)-\mathrm{MeOH}(92: 8, \mathrm{v} / \mathrm{v})$ were used as the mobile phase. The detection wavelength was set at $270 \mathrm{~nm}(72)$.

17 natural estrogenic compounds, including four steroid estrogens, six mycoestrogens, and seven phytoestrogens, in river water samples were determined by electrospray ionization sourced LC-MS/MS. C 18 column was used with the mobile phase composed of water and acetonitrile in gradient elution mode with a flow rate of $0.3 \mathrm{~mL} / \mathrm{min}$. In order to enrich the samples, MSPE was applied before the chromatographic process by using poly dopamine coated $\mathrm{Fe}_{3} \mathrm{O}_{4}$. The elution was performed with $5 \mathrm{~mL}$ methanol twice (73).

In another study, the sulfonamide antibiotics assay from environmental water samples were detected with $\mathrm{Fe}$-pamoate porous complex attached to silicacoated microspheres. For preconcentration and pretreatment,. Prior to HPLC analysis, high recoveries were obtained with this MSPE in water samples. UV detection and reverse phase chromatography were applied for the quantitation for the extraction and enrichment of SAs in tap, river and rain water samples (74).

A new polycaprolactone (PCL) coated $\mathrm{Fe}_{3} \mathrm{O}_{4}$ nanocomposite was synthesized and used as a sorbent for magnetically mediated PCL microspheressolid-phase extraction (MM-PCL-SPE) prior to gas chromatography-flame ionization detection (GC-FID) for the determination of progesterone hormone in biological and environmental matrices (tap water, urine, and hospital waste water). The nanomagnetite core of the sorbent was synthesized by a co-precipitation method. Magnetic nanoparticles (MNPs) were then microencapsulated with PCL microspheres using emulsion polymerization. High recoveries for all types of samples were achieved (75).

Table 2: The main parameters of MSPE and analytical process combination of drug determinations in environmental samples.

\begin{tabular}{|c|c|c|c|c|c|c|c|c|c|}
\hline Analyte & Matrix & MNP type & MNP synthesis method & MNP characterization & $\begin{array}{c}\text { MSPE } \\
\text { recovery \% }\end{array}$ & $\begin{array}{c}\text { Desorption } \\
\text { solvent/elution } \\
\text { process }\end{array}$ & $\begin{array}{c}\text { Additional } \\
\text { step before or after } \\
\text { MSPE }\end{array}$ & $\begin{array}{c}\text { Combined } \\
\text { analytical } \\
\text { method }\end{array}$ & Ref \\
\hline $\begin{array}{l}\text { sulfadiazine } \\
\text { sulfamerazine } \\
\text { sulfamethoxazole }\end{array}$ & waste water & $\begin{array}{l}\text { graphene oxide coated } \\
\qquad \mathrm{Fe}_{3} \mathrm{O}_{4}\end{array}$ & solvothermal & FTIR, XRD, TEM & 95.8 & $\begin{array}{c}\text { acetonitrile:5\% } \\
\text { ammonium } \\
\text { hydroxide }\end{array}$ & - & HPLC-DAD & -67 \\
\hline $\begin{array}{l}\text { sulfonamide } \\
\text { antibiotics } \\
\text { (10 samples) }\end{array}$ & milk & $\begin{array}{l}\text { graphene oxide coated } \\
\qquad \mathrm{Fe}_{3} \mathrm{O}_{4}\end{array}$ & $\begin{array}{l}\text { graphene oxidation, } \\
\text { coprecipitation }\end{array}$ & FTIR, TEM & $73.4-97.4$ & $\begin{array}{c}\text { acetonitrile:5\% } \\
\text { ammonium } \\
\text { hydroxide } \\
\end{array}$ & - & LC-MS/MS & -68 \\
\hline $\begin{array}{l}\text { estrogenic } \\
\text { compounds ( } 12 \\
\text { samples) }\end{array}$ & $\begin{array}{c}\text { mineral water } \\
\text { tap water } \\
\text { waste water }\end{array}$ & $\begin{array}{l}\text { dopamine coated } \\
\mathrm{Fe}_{3} \mathrm{O}_{4}\end{array}$ & coprecipitation & $\begin{array}{c}\text { FTIR, XRD, TEM, SEM, XRP, } \\
\text { VSM }\end{array}$ & $72-116$ & methanol & - & LC-MS & -69 \\
\hline $17 \beta$-estradiol & $\begin{array}{c}\text { environmental } \\
\text { water }\end{array}$ & $\begin{array}{l}\text { amino and aldehyde- } \\
\text { functionalized } \mathrm{Fe}_{3} \mathrm{O}_{4}\end{array}$ & $\begin{array}{l}\text { molecular imprinting } \\
\text { technique }\end{array}$ & FTIR, XRD, TEM & 88.3- 99.1 & $\begin{array}{c}\text { ethanol: acetic acid } \\
(96: 4)\end{array}$ & $\longrightarrow$ & HPLC-UV & -70 \\
\hline $\begin{array}{l}\text { ranitidine } \\
\text { hydrochloride }\end{array}$ & $\begin{array}{c}\text { human plasma } \\
\text { aquatic water }\end{array}$ & SDS coated $\mathrm{Fe}_{3} \mathrm{O}_{4}$ & $\begin{array}{l}\text { surfactant assisted } \\
\text { coprecipitation }\end{array}$ & SEM & $89-103.4$ & methanol & $\begin{array}{l}\text { protein precipitation } \\
\text { for plasma samples }\end{array}$ & UV-vis & -71 \\
\hline lamivudine & $\begin{array}{l}\text { human urine } \\
\text { river water }\end{array}$ & Ni/MWCNTs & $\begin{array}{l}\text { precipitation onto } \\
\text { MWCNTs }\end{array}$ & TEM, XRD, VSM & $>90 \%$ & ILs: $\mathrm{Na}_{3} \mathrm{PO}_{4}$ & - & HPLC-DAD & -72 \\
\hline $\begin{array}{l}\text { estrogens, } \\
\text { phytoestrogens, } \\
\text { mycoestrogens }\end{array}$ & river water & $\begin{array}{l}\text { polydopamine coated } \\
\qquad \mathrm{Fe}_{3} \mathrm{O}_{4}\end{array}$ & coprecipitation & SEM, FTIR, ATR & $>70 \%$ & methanol & - & LC-MS/MS & -73 \\
\hline $\begin{array}{l}\text { sulfadiazine } \\
\text { sulfamerazine } \\
\text { sulfadimidine } \\
\text { sulfisoxazole } \\
\text { sulfathiazole }\end{array}$ & $\begin{array}{l}\text { environmental } \\
\text { water }\end{array}$ & silica-coated $\mathrm{Fe}_{3} \mathrm{O}_{4}$ & solvothermal & TEM, FTIR & $86.3-98.9$ & $\begin{array}{l}\text { acetone:5\% } \\
\text { ammonium } \\
\text { hydroxide }\end{array}$ & - & HPLC-UV & -74 \\
\hline progesterone & $\begin{array}{c}\text { serum } \\
\text { tap water } \\
\text { urine hospital } \\
\text { waste water }\end{array}$ & $\begin{array}{l}\text { polycaprolactone } \\
\text { coated } \mathrm{Fe}_{3} \mathrm{O}_{4}\end{array}$ & $\begin{array}{l}\text { coprecipitation } \\
\text { emulsion } \\
\text { polymerization }\end{array}$ & SEM, FTIR & & & & GC-FID & -75 \\
\hline
\end{tabular}

\section{Determinations in Food Matrices}

Today, food production processes are becoming global and it is becoming difficult to control food safety and quality. For this reason, national and international regulatory committees identify and supervise relevant aspects. In the European Union, maximum residue limits (MRLs) have been established for antibacterial substances in animal-derived foods and the limits for use as feed additives have been established. For example, in the production of high quality raw milk and dairy products, antibiotic detection is carried out in various ways and controlled. Although antibiotics are classified by type of bacteria, type of activity or chemical structure, there is no method to determine all types of antibiotics. In this sense, increasing speed in detection and control has become an alternative to magnetic solid state separation in efficient new methods, which allows for high and selective separation in analytical methods. A detailed table
(Table 3) has been prepared and the details of the studies in the table are explained below.

In a study, a new method was developed for the quantitation of three tetracycline and quinolone veterinary antibiotics (oxytetracycline, tetra-cycline, chlortetracycline and three acidic quinolones, such as oxolinic acid, nalidixic acid and flumequine) in meat samples. The drug residues are very important for human health. The LOD values of the method are 1.0, 1.5, 3.8, 0.25, 0.7 and 1.2 $\mathrm{ng} / \mathrm{mL}$, which correspond to $3.3,5.0,12.7,0.8,2.3$ and $4.0 \mu \mathrm{g} / \mathrm{kg}-$ for oxytetracycline, tetracycline, chlortetra-cycline, oxolinic acid, nalidixic acid and flumequine, respectively. This quantitation level is feasible for meat analysis of food products. Ultra-high performance liquid chromatography (UHPLC) was applied with reverse phase chromatography and gradient elution profile. Detection was performed fluorimetrically. 
As an advantage of UHPLC, the analysis was completed in a short time and the resolution of peaks was high enough by the effect of $1.7 \mu \mathrm{m}$ particule sized column. Prior to UHPLC, MSPE was applied with europium- and terbium-coated $\mathrm{Fe}_{3} \mathrm{O}_{4}$ as sorbents. Besides, prior to MSPE homogenization and protein precipitation steps were carried out in order to facilitate MSPE (76).

Natamycine, which is widely used as an additive for food products to prevent the microbial contamination, was determined in jam samples by HPLC with UVVisible detector. MSPE combined with HPLC was used in order to eliminate the possible intereferences that may occur because of the complicated components of jam such as lipidic and protein based ingredients. Prior to MSPE homogenizatin and LLE were also applied to samples. As the sorbent of SPE $\mathrm{Fe}_{3} \mathrm{O}_{4} / \mathrm{SiO}_{2} /$ poly (acrylamide-N,N'-methylene bisacrylamide) microspheres modified with non-ionic triblock copolymer surfactant were synthesizde and used. For different jam samples a recovery range of 78.8-93.4\% was achieved. Reverse phase HPLC was prefered and the quantitations were carried out at 304 $\mathrm{nm}$. Retention time is about $3.5 \mathrm{~min}$ for the analyte (77).

Five sulfonamides, including sulfamerazine, sulfamethizole, sulfadoxine, sulfamethoxazole and sulfisoxazole in various milk samples were determined by HPLC with UV detection. C18 column $(4.6 \mathrm{~mm}, 150 \mathrm{~mm}, 5 \mu \mathrm{m})$ and as a mobile phase acetonitrile, water (25:75) was used. The chromtagram was completed in $8 \mathrm{~min}$ with good resolution. Prior to HPLC analysis, protein precipitation and MSPE were applied for pretreatment and enrichment. Graphen coated magnetide was used as the sorbent and synthesized according to Hummers' method.. MSPE was conducted immediately after homogenization and protein precipitation of milk samples. This method provides recoveries in a range of $62.0-104.3 \%$ for different meat samples (78).

Sulfadiazine and sulfathiazole were determined by another MSPE-HPLC combination. $\mathrm{Fe}_{3} \mathrm{O}_{4}$ was used as the extraction sorbent and provided an efficient extraction with 92.9-102.4\% recovery for both analytes from various cow milk samples that were purchased from markets. A protein precipitation pre-treatment procedure was applied before MSPE. SPE was carried out nearly in 6 min. The extract was evaporated and the residue was dissolved in the mobile phase.
The analytes were desorbed from the surface of MNPs by shaking with acetonitrile for $1 \mathrm{~min}$. C 18 column at $40^{\circ} \mathrm{C}$ and acetonitrile water combination (98:2) was used as the mobile phase. The analyte peaks were observed at $270 \mathrm{~nm}$ (79).Another study reported a MISPE-HPLC method based on determination of amphenicol antibiotics in egg, water, chicken blood. Molecular imprinting was applied to synthesise a magnetic mesoporous dual-template molecularly imprinted polymer $\left(\mathrm{Fe}_{3} \mathrm{O}_{4} @ \mathrm{mSiO} 2 @ \mathrm{DMIP}\right)$ with chloramphenicol (CAP) and florfenicol (FF) as the templates. The obtained dual template MIP was showed high adsorption capacity and good specific recognition performance for CAP and FF (80).

Fluoroquinolone drugs in foods of animal origin were analyzed with magnetic graphene as the novel sorbent combined with HPLC. Results showed that this method achieved high absorption capacities, high recoveries, high enrichment, high sensitivities, satisfactory purification effects and excellent reusability $(81)$.

In the literature, it is also found other functionalizing special molecules like organo frames or molecularly imprinted polymers adsorbed onto the surface of the MNPs for the selective interaction with a particular compound or a family of compounds in food stuff. Exemplarily a to determine four estrogens, novel molecular imprinted film coating by using magnetic ZIF composite $\left(\mathrm{Fe}_{3} \mathrm{O}_{4} @ \mathrm{ZIF}-8\right)$ as carrier was fabricated for solid phase microextraction in 24 food samples by HPLC-DAD in a study (82). In another, to testify the feasibility of the magnetic composites in sample preparation, magnetic MIPs were applied as sorbents for MSPE combined HPLC-UV of fluoroquinolones (FQs) in milk samples (83).

In the above examples of the use of magnetic nanoparticles in the environment for solid phase extraction, 17 estrogens is also studied for the determination of the amount in milk. In this study novel monodisperse molecularly imprinted layer was coated on magnetic $\mathrm{Fe}_{3} \mathrm{O}_{4} @ \mathrm{NH}_{2}$ by combining surface molecular imprinting technique (84).Similarly, in a study showed that magnetic dispersion extraction using molecularly imprinted magnetic microspheres (MIMMs) is a powerful tool for food-sample pretreatment with high selectivity and a simplified procedure for the selective clean-up and enrichment of tetracycline antibiotics from milk samples (85).

Table 3: The main parameters of MSPE and analytical process combination of drug determinations in food samples

\begin{tabular}{|c|c|c|c|c|c|c|c|c|c|}
\hline Analyte & Matrix & MNP type & MNP synthesis method & MNP characterization & $\begin{array}{c}\text { MSPE } \\
\text { recovery \% }\end{array}$ & $\begin{array}{c}\text { Desorption } \\
\text { solvent/elution } \\
\text { process } \\
\end{array}$ & $\begin{array}{c}\text { Additional } \\
\text { step before or after } \\
\text { MSPE } \\
\end{array}$ & $\begin{array}{c}\begin{array}{c}\text { Combined } \\
\text { analytical } \\
\text { method }\end{array} \\
\end{array}$ & Ref \\
\hline $\begin{array}{l}\text { oxytetracycline } \\
\text { tetracycline } \\
\text { chlortetracycline } \\
\text { oxolinic acid } \\
\text { nalidixic acid } \\
\text { flumequine }\end{array}$ & meat & $\begin{array}{l}\text { Eu and } \mathrm{Tb} \text { coated } \\
\mathrm{Fe}_{3} \mathrm{O}_{4}\end{array}$ & precipitation & XRD, TEM, XPS & $61.5-102.6$ & acetonitrile & $\begin{array}{l}\text { homogenization, } \\
\text { centrifugation }\end{array}$ & UHPLC/FL & -76 \\
\hline natamycin & jam & $\begin{array}{c}\text { surfactant } \\
\text { functionalized } \\
\mathrm{Fe}_{3} \mathrm{O}_{4} / \mathrm{SiO}_{2} / \text { poly }(\text { acryl } \\
\text { amide- }, \mathrm{N} \text { methylene } \\
\text { bisacrylamide) } \\
\text { composite }\end{array}$ & $\begin{array}{l}\text { solvothermal } \\
\text { sol-gel }\end{array}$ & SEM, TEM, FTIR, XRD, VSM & $78.8-93.4$ & $\begin{array}{c}\text { acetonitrile:water (40:60): } 0.1 \% \\
\text { TFA }\end{array}$ & LLE, homogenizaiton & HPLC-UV & -77 \\
\hline $\begin{array}{l}\text { sulfamerazine } \\
\text { sulfamethizole } \\
\text { sulfadoxine } \\
\text { sulfamethoxazole } \\
\text { sulfisoxazole }\end{array}$ & milk & $\begin{array}{l}\text { graphene coated } \\
\mathrm{Fe}_{3} \mathrm{O}_{4}\end{array}$ & $\begin{array}{l}\text { graphene oxidation, } \\
\text { coprecipitation }\end{array}$ & $\begin{array}{l}\text { SEM, FTIR, XRD, VSM, UV- } \\
\text { vis spectrometry }\end{array}$ & $62.0-104.3$ & methanol:5\% aceticacid & protein precipitation & HPLC-UV & -78 \\
\hline $\begin{array}{l}\text { sulfadiazine } \\
\text { sulfathiazole }\end{array}$ & milk & $\mathrm{Fe}_{3} \mathrm{O}_{4}$ & commercially purchased & - & $92.9-102.4$ & acetonitrile & protein precipitation & HPLC-UV & -79 \\
\hline $\begin{array}{l}\text { chloramphenicol } \\
\text { florfenicol }\end{array}$ & $\begin{array}{l}\text { egg } \\
\text { chicken } \\
\text { blood }\end{array}$ & $\mathrm{Fe}_{3} \mathrm{O}_{4} @ \mathrm{mSiO}_{2} @ \mathrm{DMIP}$ & coprecipitation & SEM, FTIR & 88.3-99.1 & acetonitrile and water $(70: 30)$ & & HPLC-UV & -80 \\
\hline $\begin{array}{l}\text { ofloxacin } \\
\text { pefloxacin } \\
\text { lomefloxacin } \\
\text { ciprofloxacin } \\
\text { enrofloxacin } \\
\text { difloxacin } \\
\text { sarafloxacin }\end{array}$ & $\begin{array}{l}\text { egg } \\
\text { bovine } \\
\text { milk } \\
\text { chicken } \\
\text { muscle }\end{array}$ & magnetic graphene & commercial & $\ldots$ & $82.4-108.5$ & $\begin{array}{c}\text { acetonitrile: } 0.05 \% \text { phosphoric } \\
\text { acid-triethylamine } \\
(\mathrm{pH} \mathrm{3.0)}\end{array}$ & & HPLC & -81 \\
\hline 4 estrogens & Fish, pork & $\mathrm{Fe}_{3} \mathrm{O}_{4} @ \mathrm{ZIF}-8 @ \mathrm{MIP}$ & $\begin{array}{c}\text { calcination } \\
\text { precipitation }\end{array}$ & - & $74-97$ & $\begin{array}{c}\text { water:acetonitrile, gradient } \\
\text { elution }\end{array}$ & & HPLC-DAD & -82 \\
\hline $\begin{array}{l}\text { Ofloxacin } \\
\text { Lomefloxacin } \\
\text { ciprofloxacin }\end{array}$ & milk & $\mathrm{Fe}_{3} \mathrm{O}_{4}-\mathrm{MIP}$ & hydrothermal & SEM & $94.0-124.4$ & $\begin{array}{c}20 \mathrm{mM} \text { phosphate buffer }(\mathrm{pH} \\
2.5) / \text { acetonitrile/ methanol } \\
(80.5: 8.5: 11,)\end{array}$ & & HPLC-UV & -83 \\
\hline 17 beta-estradiol & $\begin{array}{c}\text { environmental } \\
\text { water }\end{array}$ & $\begin{array}{l}\text { amino and aldehyde- } \\
\text { functionalized } \mathrm{Fe}_{3} \mathrm{O}_{4}\end{array}$ & $\begin{array}{l}\text { molecular imprinting } \\
\text { technique }\end{array}$ & FTIR, XRD, TEM & $88.9-92.1$ & ethanol: acetic acid (96:4) & - & HPLC-UV & -84 \\
\hline etracyclines & milk & $\begin{array}{l}\text { surface-modified } \\
\mathrm{Fe} 3 \mathrm{O} 4\end{array}$ & $\begin{array}{l}\text { molecular imprinting } \\
\text { technique }\end{array}$ & TGA, VSM & $74.5-93.8$ & $\begin{array}{c}\text { methanol/acetonitrile/oxalic } \\
\text { acid }\end{array}$ & & HPLC-UV & -85 \\
\hline
\end{tabular}




\section{CONCLUSION}

In this paper, MSPE and analytical method combinations, used for the determination of drugs in biological fluids, environmental matrices and food products, were reviewed in detail. Pre treatment/sample preparation procedure has vital importance in such complicated matrices. In all the investigated studies in this review, it was observed that, by using MNPs as an adsorbent in SPE, good recoveries were provided with simple, fast and environmentally friendly processes at room temperature. Besides, with this type of extraction, cost and solvent consumption were significantly reduced. As MNPs, various types of nanocomposites were used based on $\mathrm{Fe}_{3} \mathrm{O}_{4}$. Mostly, graphene and other carbon derivated materials such as carbon nanotubes and graphite coated $\mathrm{Fe}_{3} \mathrm{O}_{4}$ were observed. Polymeric modifications and surface functionalization attachments were also found in a respectable number of studies for all types of matrices. Generally, the research studied meat and milk samples as food matrices. MSPE occasionally causes an additional pre treatment requirement such as protein precipitation and LLE especially in meat samples. As for the biological samples, mostly we observed serum, plasma and urine. River and tap water are the main environmental samples that we observed in the literature survey. For the synthesizing process, mostly coprecipitation, aggregation, solvothermal and surface imprinting techniques were used and the magnetic products were characterized with some of the mentioned methods: SEM, TEM, FTIR, XRD, VSM, UV-Vis spectrometry, and TGA. Overwhelmingly HPLC combined to MSPE applications with different detectors such as DAD, UV-Vis, fluorimetry, and MS. In GC combinations MS and FID detections were used. There are two CE combinations reported in this review with UV and FL detections. Directly UV-Vis spectometry, fluorimetry and MS applications were also existent in the literature.

In the literature survey, different drugs were analysed by MSPE-analytical method combinations and the number of these kinds of methods increased consistently because of the advantages of MSPE. Sensitive quantitations were performed, which enable bioavailability, bioequivalance studies for biological matrices and which are able to measure environmental contamination and food quality.

MNPs are used for separation of almost all analytes, whether simple or complex. The excellent properties of MNPs, together with the advantage for use, enhance the functionalization of their surfaces. More attention should be paid to improving existing MNP synthesis methods for this, in order to develop new coatings to achieve multifunctional MNPs. The development of new designs that will enhance the interaction between the analyte and MNP surface will improve the physicochemical properties of MNPs. Development of appropriate analytical procedures for the synthesis and functionalization of MNPs and study of the conditions of the extraction process are also necessary. As a next step in the synthesis of new materials for SPE, various functionalized polymers like molecular imprinting polymers and highly cross-linked sorbents should be developed with increased. Subsequently, the development of miniaturized devices containing these new types of materials can increase the use of highefficiency systems operating with fast and accurate analytical methods for sample preparation and analysis. Finally, there is still much to be done to develop innovative MSPE systems so that NPs can be used in routine laboratory analyze of large numbers of samples.

\section{REFERENCES}

1. Płotka-Wasylka, J., Szczepanska, N., Guardia,M., and Namiesnik, J. (2016) $J$. Modern trends in solid phase extraction: New sorbent media, Trends Analyt Chem., 77:23-43.

2. Andrade-Eiroa, A., Canle, M., Leroy-Cancellieri, V., and Cerdà, V. (2016) Solid-phase extraction of organic compounds: A critical review (Part I), Trends Analyt Chem., 80:641-654.

3. M. Safarikova, I. Safarik, Magnetic solid-phase extraction, J. Magn Magn.Mater 194 (1999) 108-112

4. Ito, A., Shinkai, M., Honda, H., and Kobayashi, T. (2005) Medical application of functionalized magnetic nanoparticles. J. Biosci. Bioeng., 100:1-11.

5. Liu, G., Men, P., Harris, PL., Rolston, R.K., Perry, G., and Smith, M.A (2006) Nanoparticle iron chelators: a new therapeutic approach in Alzheimer disease and other neurologic disorders associated with trace metal imbalance, Neurosci. Lett., 406:189-193.

6. Jalilian, A.R., Panahifar, A., Mahmoudi, M., Akhlaghi, M., and Simchi, A (2009) Preparation and biological evaluation of ${ }^{67} \mathrm{Ga}$ labeled superparamagnetic nanoparticles in normal rats, Radiochim. Acta,97:51-56.
7. Bulte, J.W., Douglas, T., Witwer, B., Zhang, S.C., Strable, E., Lewis, B.K., Zywicke, H., et al. (2011) Magnetodendrimers allow endosomal magnetic labeling and in vivo tracking of stem cells. Nat. Biotechnol., 19:1141-1147.

8. Mahmoudi, M., Sant, S., Wang, B., Laurent, S., and Sen, T. (2011) Superparamagnetic iron oxide nanoparticles (SPIONs): Development, surface modification and applications in chemotherapy, Adv. Drug Deliver. Rev., 63:24-46.

9. Sugimoto, T., and Matijevic, E. (1980) Formation of uniform spherical magnetite particles by crystallization from ferrous hydroxide gels, J. Colloid Interf. Sci., 174:227-243.

10. Maity, D., Choo, S.G., Yi, J.B., Ding, J., and Xue, J.M. (2009) Synthesis of magnetite nanoparticles via a solvent-free thermal decomposition route, $J$. Magn. Magn. Mater., 321:1256-1259.

11. Grzeta, B., Ristic, M., Nowik, I., and Music, S. (2002) Formation of nanocrystalline magnetite by thermal decomposition of iron choline citrate, J. Alloy. Compd., 334:304-312.

12. Fievet, F., Lagier, J.P., Blin, B., Beaudoin, B., and Figlarz, M. (1989) Homogeneous and heterogeneous nucleations in the polyol process for the preparation of micron and submicron size metal particles, Solid State Ionics, 32:198205

13. Si, S.F., Li, C.H., Wang, X., Yu, D., Peng, Q., and Li, Y.D. (2005) Magnetic monodisperse $\mathrm{Fe}_{3} \mathrm{O}_{4}$ nanoparticles, Cryst. Growth Design, 5:391-393.

14. Durmus, Z., Baykal, A., Kavas, H., Direkçi, M., and Toprak, M.S. (2009) Ovalbumin mediated synthesis of $\mathrm{Mn}_{3} \mathrm{O}_{4}$, Polyhedron, 28:2119-2122.

15. Muller, B.W., and Muller, R.H. (1984) Particle-size distributions and particle-size alterations in microemulsions, J. Pharm. Sci., 73:919-922.

16. Alvarez, G.S., Muhammed, M., Zagorodni, A. (2006) Novel flow injection synthesis of iron oxide nanoparticles with narrow size distribution, Chem. Eng. Sci., 61:4625.

17. Denouden, C.J.J., and Thompson, R.W. (1991) Analysis of the formation of monodisperse populations by homogeneous nucleation, J. Colloid Interf. Sci., 143:77-84.

18. Baykal, A., Kavas, H., Durmus, Z., Demir, M., Kazan, S., Topkaya, R., and Toprak, M.S. (2010) Sonochemical synthesis and chracterization of $\mathrm{Mn}_{3} \mathrm{O}_{4}$ nanoparticles, Cent. Eur. J. Chem., , 8:633-638

19. Pascal, C., Pascal, J.L., Favier, F., Moubtassim, M.L.E., and Payen, C. (1999) Electrochemical synthesis for the control of gamma- $\mathrm{Fe}_{2} \mathrm{O}_{3}$ nanoparticle size.Morphology, microstructure, and magnetic behavior, Chem. Mater., 11:141-147.

20. Khollam, Y.B., Dhage, S.R., Potdar, H.S., Deshpande, S.B., Bakare, P.P., Kulkarni, S.D., and Date, S.K. (2002) Microwave hydrothermal preparation of submicron-sized spherical magnetite $\left(\mathrm{Fe}_{3} \mathrm{O}_{4}\right)$ powders, Mater. Lett., 56:571-577.

21. Bharde, A., Rautaray, D., Bansal, V., Ahmad, A., Sarkar, I., Yusuf, S.M., Sanyal, M., et al. (2006) Extracellular biosynthesis of magnetite using fungi, Small 2:135-141.

22. Kim, J., Kim, H.S., Lee, N., Kim, T., Kim, H., Yu, T., Song, I.C., et al. (2008) Multifunctional uniform nanoparticles composed of a magnetite nanocrystal core and a mesoporous silica shell for magnetic resonance and fluorescence imaging and for drug delivery, Angew. Chem. Int. Edit., 47:8438-8441.

23. Tang, D., Yuan, R., and Chai, Y. (2006) Magnetic Core-Shell $\mathrm{Fe}_{3} \mathrm{O}_{4} @ \mathrm{Ag}$ Nanoparticles Coated Carbon Paste Interface for Studies of Carcinoembryonic Antigen in Clinical Immunoassay, J. Phys. Chem. B, 110:11640-11646.

24. Pariti, A., Desai, P., Maddirala, S.K.Y., Ercal, N., Katti, K.V., Liang, X., and Nath, M. (2014) Superparamagnetic $\mathrm{Au}-\mathrm{Fe}_{3} \mathrm{O}_{4}$ nanoparticles: one-pot synthesis, biofunctionalization and toxicity evaluation, Mater. Res. Express, 1:035023.

25. Bartolozzi, C., Lencioni, R., Donati, F., and Cioni, D. (1999) Abdominal MR: liver and pancreas, Eur. Radiol., 9:1496-1512.

26. Meng, J., Fan, J., Galiana, G., Branca, R.T., Clasen, P.L., Ma, S., Zhou, J., et al. (2009) LHRH-functionalized superparamagnetic iron oxide nanoparticles for breast cancer targeting and contrast enhancement in MRI, Mater. Sci. Eng. $C, 29: 1467-1479$.

27. Horak, D., Babic, M., Jendelova, P., Herynek, V., Trchová, M., Pientka, Z., Pollert E., et al. (2007) D-mannose-modified iron oxide nanoparticles for stem cell labeling, Bioconjug. Chem., 18:635-644.

28. Andra, W., d'Ambly, C.G., Hergt, R., Hilger, I., and Kaiser, W.A. (1999) Temperature distribution as function of time around a small spherical heat source of local magnetic hyperthermia, J. Magn. Magn. Mater., 194:197203.

29. Lu, W., Ling, M., Jia, M., Huang, P., Li, C., and Yan, B. (2014) Facile synthesis and characterization of polyethylenimine-coated $\mathrm{Fe}_{3} \mathrm{O}_{4}$ 
superparamagnetic nanoparticles for cancer cell separation, Mol. Med. Rep., 9:1080-1084

30. Grumezescu, V., Holban, A.M., Grumezescu, A.M., Socol, G., Ficai, A., Vasile, B.S., Truscă, R., et al. (2014) Usnic acid-loaded biocompatible magnetic PLGA-PVA microsphere thin films fabricated by MAPLE with increased resistance to staphylococcal colonization, Biofabrication, 6:035002.

31. Yang, J., Zou, P., Yang, L., Cao, J., Sun, Y., Han, D., Yang, S., et al. (2014) A comprehensive study on the synthesis and paramagnetic properties of PEGcoated $\mathrm{Fe}_{3} \mathrm{O}_{4}$ nanoparticles, Appl. Surf. Sci., 303:425-432.

32. Zhang, Y., Liu, J.Y., Ma, S., Zhang, Y.J., Zhao, X., Zhang, X.D., and Zhang, Z.D. (2010) Synthesis of PVP-coated ultra-small $\mathrm{Fe}_{3} \mathrm{O}_{4}$ nanoparticles as a MRI contrast agent. J. Mater. Sci. Mater. Med., 21:1205-1210.

33. Trends in Analytical Chemistry 59 (2014) 50-58.

34. Zhu, L., Pan, D., Ding, L., Tang, F., Zhang, Q., Liu, Q., and Yao, S. (2010) Mixed hemimicelles SPE based on CTAB-coated $\mathrm{Fe}_{3} \mathrm{O}_{4} / \mathrm{SiO}_{2}$ NPs for the determination of herbal bioactive constituents from biological samples, Talanta, 80:1873-1880.

35. Chen, M.L., Suo, L.L., Gao, Q., and Feng, Y.Q. (2011) Determination of eight illegal drugs in human urine by combination of magnetic solid-phase extraction with capillary zone electrophoresis, Electrophoresis, 32:20992106.

36. Su, S.W., Liao, Y.C., and Whang, C.W. (2012) Analysis of alendronate in human urine and plasma by magnetic solid-phase extraction and capillary electrophoresis with fluorescence detection, J. Sep. Sci., 35:681-687.

37. Ahangar, L.E., Movassaghi, K., Bahrami, F., Enayati, M., and Chianese, A. (2014) Determination of Drugs in Biological Sample by Using Modified Magnetic Nanoparticles and HPLC, Chem. Engineer. Trans., 38:391-395.

38. Afkhami, A., Saber-Tehrani, M., and Bagheri, H. (2010) Modified maghemite nanoparticles as an efficient adsorbent for removing some cationic dyes from aqueous solution, Desalination, 263:240-248.

39. Madrakian, T., Afkhami, A., Rahimi, M., Ahmadi, M., and Soleimani, M (2013) Preconcentration and spectrophotometric determination of oxymetholone in the presence of its main metabolite (mestanolone) using modified maghemite nanoparticles in urine sample, Talanta, 115:468-473.

40. Mahdavian, A.R., and Mirrahimi, M.S. (2010) Efficient separation of heavy metal cations by anchoring polyacrylic acid on superparamagnetic magnetite nanoparticles through surface modification, Chem. Eng. J., 159:264-271.

41. Panahi, H.A., Soltani, E.R., Moniri, E., Tamadon, (2013) A. Synthesis and characterization of poly[1-(N,N-bis-carboxymethyl) amino-3-allylglycerolco-dimethylacrylamide] grafted to magnetic nano-particles for extraction and determination of letrozole in biological and pharmaceutical samples, Talanta, 117:511-517.

42. Behbahani, M., Bagheri, S., Amini, M.M., Abandansari, H.S., Moazami, H.R., Bagheri, A. (2014) Application of a magnetic molecularly imprinted polymer for the selective extraction and trace detection of lamotrigine in urine and plasma samples, J Sep Sci., 37:1610-1616.

43. Mashhadizadeh, M.H., and Amoli-Diva, M. (2013) Atomic absorption spectrometric determination of $\mathrm{Al}^{3+}$ and $\mathrm{Cr}^{3+}$ after preconcentration and separation on 3-mercaptopropionic acid modified silica coated- $\mathrm{Fe}_{3} \mathrm{O}_{4}$ nanoparticles, J. Anal. Atomic Spectrom., 28:251-258.

44. Pourghazi, K., and Amoli-Diva, M. (2014) Magnetic nanoparticles solid phase extraction based on the formation of supramolecular mixed hemimicelle aggregates for the determination of naproxen in biological fluids using high-performance liquid chromatography-UV, IET Micro \& Nano Letters, 9:577-581.

45. Shen, J., Huang, W., Wu, L., Hu, Y., and Ye, M. (2007) Study on aminofunctionalized multiwalled carbon nanotubes, Mater. Sci. Eng. A, 464:151156.

46. Daneshvar Tarigh, G., and Shemirani, F. (2013) Magnetic multi-wall carbon nanotube nanocomposite as an adsorbent for preconcentration and determination of lead (II) and manganese (II) in various matrices, Talanta, 115:744-750

47. Bigdelifam, D., Mirzaei, M., Hashemi, M., Amoli-Diva, M., Rahmani, O., Zohrabi, P., Taherimaslak, Z., et al. (2014) Sensitive spectrophotometric determination of fluoxetine from urine samples using charge transfer complex formation after solid phase extraction by magnetic multiwalled carbon nanotubes, Anal. Methods, 6:8633-8639.

48. Zhang, H., and Shi, Y. (2012) Preparation of $\mathrm{Fe}_{3} \mathrm{O}_{4}$ nanoparticle enclosure hydroxylated multi-walled carbon nanotubes for the determination of aconitines in human serum samples, Anal. Chim. Acta, 724:54-60.

49. Zhang, S.L., Cui, Y.H., Sun, J.C., Xi, Y.Q., Zhang, C.X., and Tang, J.H., (2015) Sensitive magnetic solid-phase microextraction based on oxide multi- walled carbon-nanotubes for the determination of methylamphetamine and ketamine in human urine and blood, Anal. Methods, 7:4209-4215.

50. Madrakian, T., Haryani, R., Ahmadi, M., and Afkhami, A., (2015) Spectrofluorometric determination of venlafaxine in biological samples after selective extraction on the superparamagnetic surface molecularly imprinted nanoparticles, Anal. Methods, 7:428-435.

51. Ebrahimi, M., Ebrahimitalab, A., Eshaghi, Z., Mohammadinejad, A., (2015) Magnetized Silane-Coupling Agent KH-570 Based Solid-Phase Extraction Followed by Gas Chromatography-Flame Ionization Detection to Determine Venlafaxine in Human Hair and Aqueous Environmental Samples, Arch. Environ. Contam. Toxicol., 68:412-420.

52. Chen, D., Zheng, H.B., Huang, Y.Q., Hu, Y.N., Yu, Q.W., Yuan, B.F., and Feng, Y.Q. (2015) Magnetic solid phase extraction coupled with desorption corona beam ionization-mass spectrometry for rapid analysis of antidepressants in human body fluids, Analyst, 140:5662-5670.

53. Ahmadi, M., Madrakian, T., and Afkhami A. (2016) Solid phase extraction of amoxicillin using dibenzo-18-crown-6 modified magnetic-multiwalled carbon nano tubes prior to its spectrophotometric determination, Talanta, 148:122-128.

54. Madrakian, T., Fazl, F., Ahmadi, M., and Afkhami, A., (2016) Efficient solid phase extraction of codeine from human urine samples using a novel magnetic molecularly imprinted nanoadsorbent and its spectrofluorometric determination, New J. Chem., 40:122-129.

55. Chen, D., Zheng, H.B., Huang, Y.Q., Hu, Y.N., Yu, Q.W., Yuan, B.F., and Feng, Y.Q. (2015) Magnetic solid phase extraction coupled with desorption corona beam ionization - mass spectrometry for rapid analysis of antidepressants in human body fluids, Analyst, 140:5662-5670.

56. Zeng, S., Gan, N., Weideman-Mera, R., Cao, Y., Li, T., and Sang, W. (2013) Enrichment of polychlorinated biphenyl 28 from aqueous solutions using $\mathrm{Fe}_{3} \mathrm{O}_{4}$ grafted graphene oxide, Chem. Eng. J. 218:108.

57. Taghvimi, A., Hamishehkar, H., and Ebrahimi, M. (2016) The application of magnetic nano graphene oxide in determination of methamphetamine by high performance liquid chromatography of urine samples, J. Iran. Chem. Soc., 13:1471-1480.

58. Taghvimi, A., Hamishehkar, H., and Ebrahimi, M. (2016) Magnetic nano graphene oxide as solid phase extraction adsorbent coupled with liquid chromatography to determine pseudoephedrine in urine samples, $J$. Chromatogr. B, 1009:66-72.

59. Bykkam, S., Rao, K., Chakra, C., and Thunugunta, T. (2013) Synthesis and characterization of graphene oxide and its antimicrobial activity against klebseilla and staphylococcus, Int. J. Adv. Biotechnol. Res., 4:1005-1009.

60. Zeng, S., Gan, N., Weideman-Mera, R., Cao, Y., Li, T., and Sang, W. (2013) Enrichment of polychlorinated biphenyl 28 from aqueous solutions using $\mathrm{Fe}_{3} \mathrm{O}_{4}$ grafted graphene oxide, Chem. Eng. J., 218:108-115.

61. Taghvimi, A., Hamishehkar, H., and Ebrahimi, M. (2016) Development and validation of a magnetic solid-phase extraction with high-performance liquid chromatography method for the simultaneous determination of amphetamine and methadone in urine, $J$ Sep Sci., 39:2307-2312.

62. Xue, X., Yang, D., Wang, D., Xu, X., Zhu, L., and Zhao, Z. (2015) Solidification of floating organic drop liquid-phase microextraction cell fishing with gas chromatography-mass spectrometry for screening bioactive components from Amomum villosum Lour, Biomed. Chromatogr., 29:626632.

63. Tankiewicz, M., Morrison, C., and Biziuk, M. (2013) Application and optimization of headspace solid-phase microextraction (HS-SPME) coupled with gas chromatography-flame-ionization detector (GC-FID) to determine products of the petroleum industry in aqueous samples, Microchem. J., 108:117-123.

64. Ghorbani, M., Chamsaz, M.,Rounaghi, and G.H. (2016) Ultrasound-assisted magnetic dispersive solid-phase microextraction: A novel approach for the rapid and efficient microextraction of naproxen and ibuprofen employing experimental design with high-performance liquid chromatography, J. Sep Sci., 39:1082-1089.

65. Maham, M., and Sharifabadi, M.K., (2016) Simultaneous determination of trace amounts of anti-hypertensive drugs in urine using magnetic mixed hemimicelles solid-phase extraction combined with HPLC-UV, J. Anal. Chem., 71:302-309.

66. Tang, M., Wang, Q., Jiang, M., Xu, L., Shi, Z.G., Zhang, T., and Liu, Y. (2014) Magnetic solid-phase extraction based on methylcellulose coated$\mathrm{Fe}_{3} \mathrm{O}_{4}-\mathrm{SiO}_{2}$-phenyl for HPLC-DAD analysis of sildenafil and its metabolite in biological samples, Talanta, 130:427-432.

67. Wu, J., Zhao, H., Chen, R., Pham-Huy, C., Hui, X., and He, H. (2016) Adsorptive removal of trace sulfonamide antibiotics by water-dispersible 
magnetic reduced graphene oxide-ferrite hybrids from wastewater, $J$. Chromatogr. A, 1029-1030:106-112.

68. Wang, Y., Liu, L., Xiao, C., Chen, L., Yang, P., Liu, Q., Wang J., et al. (2016) Rapid Determination of Trace Sulfonamides in Milk by Graphene OxideBased Magnetic Solid Phase Extraction Coupled with HPLC-MS/MS, Food Anal. Method., 9: 2521.

69. Socas-Rodríguez, B., Hernández-Borges, J., Salazar, P., Martín, M., and Rodríguez-Delgado M.Á. (2015) Core-shell polydopamine magnetic nanoparticles as sorbent inmicro-dispersive solid-phase extraction for the determination ofestrogenic compounds in water samples prior to highperformanceliquid chromatography-mass spectrometry analysis, $J$. Chromatogr. A, 1397:1-10.

70. Haoa, Y., Gao, R., Shia, L., Liu, D., Tang, Y., and Guo, Z. (2015) Watercompatible magnetic imprinted nanoparticles served assolid-phase extraction sorbents for selective determination of trace 17beta-estradiol in environmental water samples by liquid chromatography, J. Chromatogr. A, 1396:7-16.

71. Konoz, E., Sarrafi, A.H.M., and Sahebi, H. (2016) Preconcentration and determination of ranitidine hydrochloride in real samples by using modified magnetic iron oxide nanoparticles, Canad. J. Chem., 94:9-14.

72. Wang, L., Xu, X., Zhang, Z., Zhang, D., Liu, X., and Zhang, L. (2015) Green sample clean-up based on magnetic multiwalled carbon nanotubes for the determination of lamivudine by high performance liquid chromatography, RSC Adv., 5:22022-22030.

73. Capriotti, A.L., Cavaliere, C., La Barbera, G., Piovesana, S., Samperi, R., Chiozzi, R.Z., Lagana, A., (2016) Polydopamine-coated magnetic nanoparticles for isolation and enrichment of estrogenic compounds from surface water samples followed by liquid chromatography-tandem mass spectrometry determination, Anal. Bioanal. Chem., 408:4011-4020.

74. Wang, H., Liu, S.Y., Lv, X.J., Rui, M., and Zhang, Z.Q. (2015) Assembly of a Fe-pamoate porous complex on magnetic microspheres for extraction of sulfonamide antibiotics from environmental water samples, Anal. Methods, 7:4939.

75. Es'haghi, Z., Nezhadali, A., Khatibi, A.D., (2016) Magnetically responsive polycaprolactone nanoparticles for progesterone screening in biological and environmental samples using gas chromatography, Anal. Bioanal. Chem., 408:5537-5549.

76. Castillo-García, M.L., Aguilar-Caballos, M.P., and Gómez-Hens, A. (2015) A europium- and terbium-coated magnetic nanocomposite as sorbentin dispersive solid phase extraction coupled with ultra-high performance liquid chromatography for antibiotic determination in meat samples, $J$. Chromatogr. A, 1425:73-80.

77. Tian, M., Zou, Y., Zhou, S., Wang, T., Lv, X., Qiong J. (2015) Development of novel magnetic solid phase extraction materials based on $\mathrm{Fe}_{3} \mathrm{O}_{4} / \mathrm{SiO}_{2} /$ poly(acrylamide-N,N-methylenebisacrylamide)-Pluronic $\quad \mathrm{L} 64$ composite microspheres and their application to the enrichment of natamycin, J. Chromatogr. B, 1007:1-7.Li, Y., Wu, X., Li, Z., Zhong, S., Wang, W., Wang, A., and Chen, J. (2015) Fabrication of $\mathrm{CoFe}_{2} \mathrm{O}_{4}$-graphene nano composite and its application in the magnetic solid phase extraction of sulfonamides from milk samples, Talanta, 144: 1279-1286.

78. Li, Y., Wu, X., Li, Z., Zhong, S., Wang, W., Wang, A., and Chen, J. (2015) Fabrication of $\mathrm{CoFe} 2 \mathrm{O} 4-$ graphene nano composite and its application in the magnetic solid phase extraction of sulfonamides from milk samples, Talanta, 144: $1279-1286$.

79. Karami-Osboo, R., Miri, R., Javidnia, K., Shojaee, M.H., Kobarfard, F. (2016) Extraction and determination of sulfadiazine and sulfathiazole in milk using magnetic solid phase extraction-HPLC-UV, Anal. Methods, 7:15861589 .

80. Wei, S., Li, J., Liu, Y., Jinkui Ma, J. (2016) Development of magnetic molecularly imprinted polymers withdouble templates for the rapid and selective determination ofamphenicol antibiotics in water, blood, and egg samples, Journal of Chromatography A, 1473:19-27.

81. He, X., Wang, G.N., Yang, K., Liu, H.Z., Wu, X.J., Wang, J.P. (2017) Magnetic graphene dispersive solid phase extraction combining high performance liquid chromatography for determination of fluoroquinolones in foods, Food Chemistry, 221:1226-1231

82. Lan, H., Gan, N., Pan, D., Hu, F., Li, T., Long, N., Shen, H., Feng, Y. (2014) Development of a novel magnetic molecularly imprinted polymercoating using porous zeolite imidazolate framework- 8 coatedmagnetic iron oxide as carrier for automated solid phasemicroextraction of estrogens in fish and pork samples, Journal of Chromatography A, 1365:35-44.

83. Zheng, H., Mo, J., Zhang, Y., Gao, Q., Ding, J., Yu, Q.W., Yu-Qi Feng, Y. (2014) Facile synthesis of magnetic molecularly imprinted polymers and its application in magnetic solid phase extraction for fluoroquinolones in milk samples, Journal of Chromatography A, 1329 :17- 23.

84. Gao, R., Cui, X., Hao, Y., Zhang, L., Liu, D., Tang, Y. (2016) A highlyefficient imprinted magnetic nanoparticle for selective separation and detection of 17ß-estradiol in milk, Food Chemistry 194:1040-1047.

85. Yv, Y.K., Zhao, C.X., Li, P., He, Y.D., Yang, Z.R., Sun, H.W. Preparation of doxycycline-imprinted magnetic microspheres by inverse-emulsion suspension polymerization for magnetic dispersion extraction of tetracyclines from milk samples, Journal of Separation Science, doi: $10.1002 /$ jssc. 201300429 . 